\title{
"QUEENLESSNESS," WORKER SIBSHIP, AND COLONY VERSUS POPULATION STRUCTURE IN THE FORMICID GENUS RHYTIDOPONERA
}

\author{
By Caryl P. Haskins ${ }^{1}$ and Roy M. Whelden ${ }^{2}$
}

\section{INTRODUCTION}

William Morton Wheeler, in his Colony Founding Among Ants (1933), called special attention to the fact that in a number of formicid genera, and particularly in the socially primitive subfamilies Ponerinae and Cerapachyinae, typical alate female forms have never been described. In such genera as Onychomyrmex, Eusphinctus, Acanthostichus, Megaponera, and Plectroctena, this normal female may be replaced by a wingless ergatogyne, intermediate in structure between queen and worker. The same condition obtains among certain species of the archaic subfamily Myrmeciinae, as Wheeler also pointed out. In some cerapachyine species, normal females typically coexist with ergatogynes, and such caste duality occurs elsewhere also.

In certain respects, the shift from a "queen-like" toward a "workerlike" form of reproductive female is curious and striking. At first sight it may even suggest a reversal of the trend tending to emphasize the dichotomy between more "vegetative" and more actively "foraging" forms which, as Wigglesworth (1954) and Kennedy (I96r) have pointed out, is so characteristic of evolution in insects generally, whether at the level of "successive polymorphism" in the juvenile and adult phases of the individual, or of "alternative polymorphism" among adult populations of such forms as aphids, migratory locusts, and the social insects. Among the ant genera cited, however, evolution from alate to ergatoid reproductive may only superficially appear to lie in that direction, for the ergatoid is clearly at least as effective a reproductive as the winged female. In most species with such females, moreover, it seems likely that the ergatoid has been directly derived by a stabilization of a queen-worker intercaste, as Brown (1960) has suggested, and merely replaces the normal queen, with no drastic change in the general economy or structure of the colony. Even in the ponerine genus Leptogenys sens. str., where the laying female is no longer morphologically distinguishable from the worker, the course of evolution still seems relatively clear. As Wheeler (1933) pointed out, a normal female is present in the related Lobopelta langii, and

${ }^{1}$ Carnegie Institution, Washington, D.C.

${ }^{2}$ Haskins Laboratories, New Durham, New Hampshire 
in L. ergatogyna the wingless laying female still possesses well developed ocelli and a normal female thorax. In the genus Myrmecia similar series, ranging through increasing female microptery toward total aptery, can be assembled, culminating in the ergatoid-like gynes of, for instance, $M$. tarsata. In all these species, however, there is little evidence of any significant modification in the social structure of the colony, which remains at base a typically matrifilial community.

Certain other ponerine genera referred to by Wheeler, however, may present a rather different picture. In the genera Diacamma, Streblognathus, and Dinoponera, and in some species of Rhytidoponera, for example, distinguishable ergatogynes have not been reported. A male of a Philippine species of Diacamma has been described in copula with a form indistinguishable from a worker by Wheeler and Chapman ( 1922), suggesting that in this organism the normal reproductive may have been replaced by what is in effect a worker-producing worker. Our overall knowledge of the first three genera, however, is hardly sufficient to support even speculation about their social situations at present. For the genus Rhytidoponera, however, something more is known or knowable, and it may quite possibly represent a situation of considerable interest to the student of social evolution in the Formicidae.

The Ponerine genus Rhytidoponera comprises an extensive but relatively compact series of species inhabiting the Australian and parts of the Melanesian and Malaysian areas, ranging from New Caledonia in the east through New Guinea and neighboring parts of Melanesia to Timor, the Moluccas, and the southern Philippines in the west and occcupying a large portion of the Australian continent and of Tasmania (Brown, 1954, I958; Wilson, 1958, 1959a). They are members of the widely distributed ponerine tribe Ectatommini, bearing considerable resemblance in many respects to the generalized New World tropical genera Acanthoponera and Ectatomma, as well as to the pantropical Heteroponera, with the Old World components of which they may well have shared common ancestry. The females of Ectatomma and Acanthoponera, so far known, are of the normal winged form. Those of Heteroponera may be winged or ergatoid.

In at least three species of Rhytidoponera, $R$. impressa, $R$. purpurea, and $R$. chalybaeae, typical winged queens are the rule. Normally a single queen is found in each colony examined in the field, and communities appear to be initiated by isolated dealated females following a normal Ponerine dispersion and mating flight. These species are confined in distribution to well-watered and warmer areas, ranging from New Guinea and eastern Queensland rain forest southward 
along a belt down the eastern edge of Australia at least as far as south central Victoria (Brown, 1958).

In a second and much larger group of Rhytidoponera species, an exactly opposite situation obtains with respect to the queen. Many of these species include among the largest and most conspicuous members of the genus, are widely distributed, abundant, and well known, especially in the drier areas of Australia, and have been extensively collected over long periods. Yet in none of them has a reproductive morphologically or functionally distinguishable from a normal worker ever been described.

Finally there is a third group, designated by Brown (1958) the Rhytidoponera metallica complex, which may be the most interesting from the standpoint of social evolution. The type species is one of the most widely distributed and ubiquitous of Australian ants; an inhabitant of thickly populated as well as remote situations over a very large area both temperate and subtropical; and so familiar as to have been known to a wide public for many years by the popular name of "greenhead" ant. Alate typical queens of this species have been described, and are represented in limited numbers in some collections, notably that of the Harvard Museum of Comparative Zoology. Wheeler described a single dealate and possibly colony-founding female of $R$. inornata, a member of the complex from southwestern Australia in 1931 (Brown, 1958). Brown (1958) has described a dealate female of another related species, $R$. aspera, collected by $H$. Hacker in southeastern Queensland and also in the Harvard Museum of Comparative Zoology. A single perfect female of $R$. victoriae, taken by Brown at Seaford, Victoria, is in the same collection. But it is striking that so few typical females have been identified in a complex of species as extraordinarily abundant and well-collected. It is clear that the vast majority of colonies in nature must exist without such females.

Even more interesting is the fact that in no species of Rhytidoponera, including those of the metallica complex, has a queen-worker intermediate ever been recorded. This could suggest that evolution to the loss of the typical female took a somewhat different course from that in the Lobopelta-Leptogenys complex or even in Heteroponera. Instead of the alate female reproductive being morphologically modified toward a stabilized intermediate between queen and worker while continuing the same functional role in the colony, the original queen caste may have disappeared entirely and one or more laying workers substituted as the usual reproductives. If, as Carroll Williams (in Brown, I960) has suggested, worker development in ants is due to a 
precocious decline of juvenile hormone titer in the maturing larva, or if on the other hand as Brian (1959, I96I) proposes, to a sharp rise in the concentration of ecdyson near the critical period or periods of caste determination in larval ontogeny, it seems conceivable that mutations have accumulated in evolution affecting neurosecretory products or processes or timing, such that the threshold for workerqueen determination is passed only rarely in species of the $R$. metallica complex, and never in many of the larger species. Alternatively, it is conceivable that dimorphic female reproductive forms originally existed, as they presently do, for example, in species of Neophyrcaces, one form being ergatoid and the other unmodified, and that further evolution resulted in the loss of the latter and so close an approximation of the worker form by the former that it is no longer distinguishable except through its reproductive capacity. If the latter course has been the actual one, however, we should perhaps suspect that the fertile "workers" would be comparatively rare in the Rhytidoponera colony, at least as rare as are the laying true queens in colonies of relatively primitive pleometrotic species. It appears, as will later be indicated, that they are in fact much more abundant.

Whatever the channel of evolution at the level of individual morphology, its end result poses some intriguing questions about the direction of evolution in Rhytidoponera at the level of the society. Some years ago Sturtevant (I938), and later Williams and Williams ( I957), emphasized the evolutionary significance of the close family relationships which typically obtain among the members of the matrifilial colony so characteristic of the higher social Hymenoptera. Very recently W. D. Hamilton (1964), in two important papers, beginning with Haldane's (1955) concept of the evolutionary significance of genetically based altruistic behavior, has derived a quantity in social evolution that he defines as "inclusive fitness." It may be regarded in certain respects as an analogue at the social level of the concept of Darwinian reproductive fitness at the level of the individual. Like the latter it should be found to maximize in evolution. This maximization, in the social insects, has obviously involved an extraordinary evolution of worker altruism, at both structural and behavioral levels. Now as Hamilton demonstrates, it can be expected that such an evolution will be positively correlated with the maintenance of close genetic relatedness among the members of a colony. In the absence of parthenogenesis, the closest genetic relationship between queen and worker possible in a colony is that of mother to daughter, and among workers that of siblings. The pronounced evolutionary trends toward the inclusion of but two generations in the 
colony structure and toward the restriction of fertilized reproductives in the colony to a single or a few individuals, so evident in a great number of ant species, both evidently contribute to maintaining this maximal degree of relatedness within the community.

Exceptions to both trends, to be sure, are known. On the one hand, they are well illustrated by the puzzling situations explored in species of the Formica obscuriventris group (King, 1949, I955; King and Sallee, I95I) and the Formica rufa group (Sturtevant, I938; Chauvin, Courtois, and Lecompt, 1961) where it appears that young reproductives, even of different species, may be adopted by large colonies, thus prolonging the existence of the colony well beyond the second generation and introducing both multiple queens and what must be a remarkable degree of unrelatedness among the worker personnel of individual colonies. Exceptions to the second trend may be presented by the numerous pleometrotic species of ants, though it is still unclear, as in the Polybiine and Polistine wasps, how usually such multiple reproductives are in fact sisters, and how often or how elaborately special behavior patterns may be adapted to restricting reproduction in practice to a single dominant female, or to preventing non-sisters from coexisting in the colony.

In this context, the course of social evolution in the genus Rhytidoponera is of special interest, as is the probable degree of average relatedness among the workers of a single community of both normal and "queenless" forms. In the so-called "queenless" species, do workers in fact regularly give rise to workers? Is the same true of those species possessing functional typical queens? Is worker production accomplished in one or both groups through parthenogenetic thelytoky, so common among lower nonsocial Hymenoptera, and frequently reported in the Cape honey bee? Such thelytoky has been described in ants by several investigators over a long period of years, including Reichenbach (I902), Crawley (I912), and Comstock ( 1903) for Lasius niger, Haskins and Enzmann ( 1945) for Aphaenogaster picea and A. lamellidens, Soulié ( I960) for Cremastogaster, and Otto ( 1960) for Formica polyctena, while Ledoux ( 1949, I954) has reported extensively on a specialized social adaptation of thelytoky in the workers of Oecophylla. If such thelytoky obtains in Rhytidoponera, the pattern of relatedness among colony members might be quite different than if laying workers possess developed spermatheca and are fertilized in the manner normal to ordinary ergatoid queens, by active low-flying males from other colonies. Such males are indeed characteristic of all species of Rhytidoponera, both those possessing and those lacking typical queens. Do laying workers 
of the "queenless" species occur only one to a colony, or are they present in some numbers? If the latter, are they commonly actual siblings, or how closely are they, on average, related? Is there a tendency, in the "queenless" species, to confine worker production to a single individual even if a number of potential worker-producers are present? If such laying workers are in fact fertilized, are their mates normally derived from the same or from other colonies? Are such workers singly or multiply inseminated? Is a single individual inseminated more than once during its lifetime? What is the average contribution of male progeny by the non-fertilized members of the colony, and how is the production of males regulated? How resistant is the genus to extreme inbreeding? Is it the rule that a proportion of each successive brood of workers brought to maturity in a colony is fertilized and that these individuals remain with the parent colony, so prolonging the life of the community well beyond the normal two generations, or do newly fecundated workers typically leave the parental nest? How indeed are new colonies normally formed?

Such questions as these must be answered before any critical assessment of the direction of social evolution in Rhytidoponera can be undertaken. The results reported in the present paper, derived in the course of some ten years of investigation of the genus both in the field and in the artificial nest, represent the early stages of an observational attempt to provide answers to a very few of them.

\section{SOURCE OF WORKER AND MALE BROOD IN A SPECIES OF RHYTIDOPONERA POSSESSING NOR'MAL QUEENS \\ Rhytodoponera purpurea}

Rhytidoponera purpurea is a typical member of the $R$. impressa group, in which normal queens are characteristic. A single such queen is typically found in each colony taken in the field. According to Brown (1954) the species occurs in New Guinea and ranges in Australia through the rain forests of the Cairns-Atherton Tableland region of northern Queensland.

On December 27, I963, a typical, populous colony of $R$. purpurea, comprising the parent female, some 250 workers, and numerous larval and pupal brood including sexual males and females, was collected near Kuranda in northern Queensland. The following day a similar colony was taken at Millaa Millaa on the Atherton Tableland. In early January these colonies were housed in a type of modified earthcontaining glass Lubbock nest used throughout these investigations. The colony from Kuranda was divided at the time of nesting into several isolated groups of workers with broods of cocoons and larvae. Only one such group had access to the brood female. The colony 
from Millaa Millaa was divided into two portions, one with and one without the brood queen. An interval was then allowed to permit the maturation of larvae and pupae in the nests at the time of capture. In the fragments of both colonies lacking parent queens, as well as in those where the normal females were present, oviposition soon occurred, and fairly copious broods were shortly reared. By late March abundant pupae were present in several groups. In that month, and over a following period until mid-January, 1965, samples of cocoons were regularly withdrawn from these colony-fragments and opened, and their contained pupae scored for sex and caste. The results, in which the numbers of pupae in all the queenless fragments of Colony No. I are summed for each date, appear below:

\begin{tabular}{|c|c|c|c|c|c|}
\hline $\begin{array}{c}\text { No. of Colony } \\
\text { Fragment } \\
\end{array}$ & $\begin{array}{r}\text { Dates of } \\
\text { Examination } \\
\end{array}$ & $\frac{\text { Ass: }}{n}$ & ay of Pupal and & Young & $\frac{\text { Adult }}{\text { Males }}$ \\
\hline $\begin{array}{l}\text { A (Kuranda- } \\
\text { with parent } \\
\text { female) }\end{array}$ & $\begin{array}{r}4 / 29 / 64 \\
6 / 4 / 64 \\
7 / 12 / 64 \\
9 / 20 / 64 \\
12 / 5 / 64 \\
1 / 19 / 65\end{array}$ & $\begin{array}{l}23 \\
14 \\
15 \\
15 \\
34 \\
30\end{array}$ & $\begin{array}{l}\text { pupae; } 3 \text { callows } \\
\text { pupae; } \\
\text { pupae; } 1 \text { callow } \\
\text { pupae } \\
\text { pupae } \\
\text { pupae }\end{array}$ & $\begin{array}{l}0 \\
0 \\
0 \\
0 \\
0 \\
0\end{array}$ & \\
\hline
\end{tabular}

$\begin{array}{lrlr}1 \text { B-E (Kuranda }- & 4 / 29 / 64 & 0 & 47 \text { pupae; } 26 \text { adults } \\ \text { fragments of } & 5 / 10 / 64 & 0 & 3 \text { pupae } \\ \text { colony without } & 6 / 4 / 64 & 0 & 12 \text { pupae } \\ \text { brood queen) } & 7 / 12 / 64 & 0 & 10 \text { pupae } \\ & 9 / 20 / 64 & 0 & 27 \text { pupae } \\ & 12 / 5 / 64 & 0 & 34 \text { pupae } \\ & 1 / 19 / 65 & 0 & 47 \text { pupae } \\ & \text { Total: } 180 \text { male pupae; } 26 \text { male adults; } 0 \text { workers. }\end{array}$

$\begin{array}{lrrll}2 \text { A (Millaa-Millaa } & -4 / 29 / 64 & 23 \text { pupae; } 2 \text { callows } & 0 \\ \text { with parent } & 6 / 4 / 64 & 39 \text { pupae } & 0 \\ \text { female) } & 6 / 22 / 64 & 1 \text { pupa } & 0 \\ & 12 / 5 / 64 & 32 \text { pupae } & 0 \\ & 1 / 19 / 65 & 29 \text { pupae } & 0\end{array}$

Total: 124 worker pupae; 2 callow workers; 0 males.

$\begin{array}{lrrr}2 \text { B (Millaa-Millaa }-~ 4 / 29 / 64 & 3 \text { callows* } & 15 \text { pupae } \\ \text { fragment without } & 6 / 4 / 64 & 0 & 5 \text { pupae } \\ \text { parent female) } & 6 / 22 / 64 & 0 & 4 \text { pupae } \\ & 9 / 20 / 64 & 0 & 8 \text { pupae } \\ & 12 / 5 / 64 & 0 & 14 \text { pupae } \\ & 1 / 19 / 65 & 0 & 14 \text { pupae } \\ & & \text { Total: } 60 \text { male pupae; } 3 \text { callow workers.* }\end{array}$

"These callow workers, found fresh-hatched on April 29, 1964, almost certainly represent the final fragment of maturing brood collected with the original colony, and seem with little doubt to have been progeny of the fertilized brood female. 
Thus, summing the output of the two colonies together over the period of approximately a year after observation was begun, those fragments containing a brood queen produced a total of 255 pupae which wैere identified as workers, 6 identifiably callow workers, and no males. Those fragments of both colonies containing workers only brought to maturity a total of 240 pupae identified as males and 26 identified young adult males, a total of 266 males. In Colony No. 2 B, three callow workers were also brought to maturity at the time of an early count. It seems a safe assumption, however, that these individuals represented the final, delayed residual of queen-laid brood "inherited" from the partitioning of the colony some three months earlier.

Thus it seems very clear that in $R$. purpurea worker brood is entirely derived from the fertilized brood female in typical Formicid fashion. Workers, however, can produce and rear a prolific male brood, at least in the absence of the parent female. Whether the male brood which typically appears seasonally in large numbers in normal wild colonies is queen- or worker-derived, or both, is an interesting and important question for future investigation. It applies with equal cogency, of course, to the vast range of "normal" Formicid species.

\section{SOURCE OF WORKER AND MALE BROOD IN SPECIES WHERE NORMAL QUEENS ARE RARE OR ABSENT}

\section{Rhytidoponera metallica}

Between December 23 and 25, 1963, a number of vigorous colonies of Rhytidoponera metallica were collected at various points in the Blackall Range in Queensland, Australia, some sixty miles north and thirty miles east of Brisbane. No perfect females were found. These colonies were housed and maintained in modified glass Lubbock nests of the same design as those used for $R$. purpurea. After a preliminary incubation period of approximately six months, to allow brood resident in the colonies at the time of capture to mature, samples of cocoons were withdrawn at intervals, opened, and the contained pupae scored for sex and caste. Callow workers that were obviously fresh-hatched were scored at the same time. The result are given in the table below (p. 95).

Thus a total of 644 worker pupae or young adults were produced in the five "queenless" colonies of $R$. metallica over a period of little more than six months, and only i I males. It seems clear that worker production by morphological workers is a normal feature of this species. 


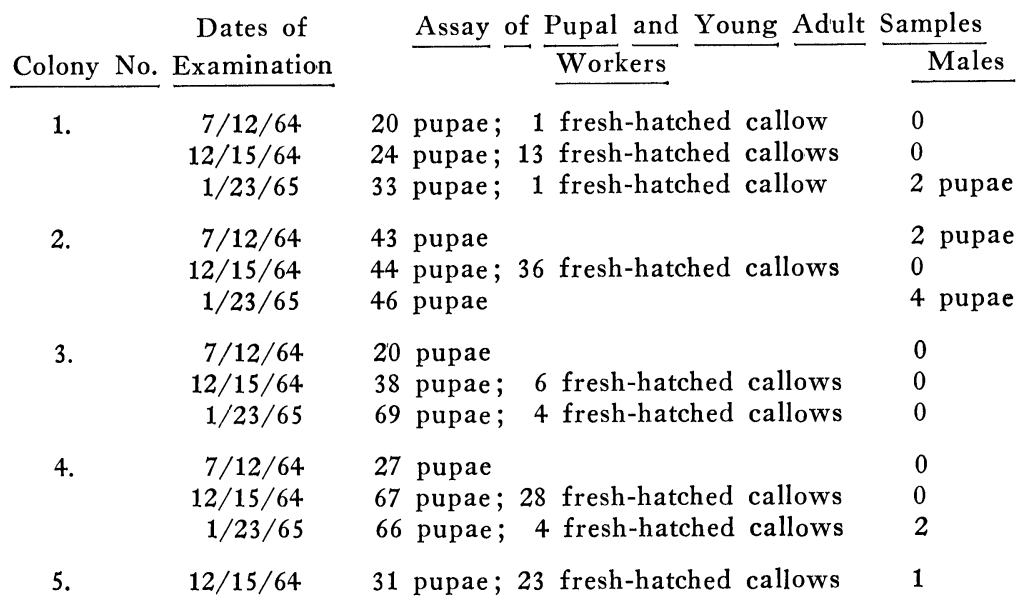

Queensland appears to lie near the northern limit of the natural range of $R$. metallica. Ample confirmation that the same situation obtains elsewhere in its range, however, was provided by counts made from a single colony of the species taken at Sutherland, N. S. W., on June 2, 1952, and observed continuously in the artificial nest over a ten-year period. This colony contained no typical females when collected, though much later in its history some were produced, as will be described later. It was kept as a single unit in the standard glass modified Lubbock type of nest until July 8, 1956, when it was split into three portions, one of which perished rather shortly. The second and third were maintained in Lubbock nests until January I, 1962, when the second also died out. The third portion survived somewhat longer, but eventually perished on July 30, 1962.

Throughout the ten years of observation, these two colony fragments were kept in closed foraging arenas, to which no males could enter from outside and from which no individuals matured within could escape. The ants established and maintained regular kitchenmiddens within these arenas, outside the nests proper. The ambient humidity of the arenas was maintained low, and the contents of the middens therefore remained well preserved and readily recognizable for considerable periods. Thus periodic removal of the middens and examination of their contents could provide a rather accurate picture of the quality and type of brood produced.

Until June 13, I954 (two years after observation was begun), only workers were brought to maturity. A count of cocoon fragments accumulated in the middens at intervals during this period thus 
offered a measure of the number of workers produced from worker parentage. Only cocoon fragments were tallied which either were nearly intact or which included the larval meconium, thus ensuring that each fragment represented no more than one individual.

Between January 30, I954, and March I3, I954, I472 such cocoon-fragments were counted, representing the workers arising from worker parentage in a typical one and one-half months' production for that period.

\section{Rhytidoponera tasmaniensis}

$R$. tasmaniensis is a species closely allied to $R$. metallica and resembling it closely in both habitus and ethology. It is characterized by a relatively southern distribution in Australia, including south Victoria and Tasmania.

A colony of $R$. tasmaniensis was collected at Lower Fern Tree Gully Station, Victoria, on January 2, 1962, and a number of further colonies were taken in the Domain at Hobart, Tasmania, on January IO and II.* None contained perfect females. All these colonies were housed in the usual glass modified Lubbock nests. On May I9 and on subsequent dates samples of cocoons were removed, and opened and assayed for sex and caste as usual. The results follow:

\begin{tabular}{|c|c|c|c|c|}
\hline$\frac{\text { Colony }}{\text { No. }}$ & $\frac{\text { Dates of }}{\text { Examination }}$ & Assay of & $\frac{\text { Pupal }}{\text { Workers }} \frac{\text { and }}{\text { Young }}$ & $\frac{\text { Samples }}{\text { Males }}$ \\
\hline 1. & $\begin{array}{l}5 / 19 / 62 \\
9 / 17 / 62 \\
1 / 5 / 63 \\
2 / 9 / 63 \\
3 / 10 / 63 \\
3 / 1 / 64 \\
9 / 20 / 64\end{array}$ & $\begin{array}{l}17 \text { pupae } \\
37 \text { pupae; } \\
24 \text { pupae } \\
27 \text { pupae } \\
18 \text { pupae } \\
24 \text { pupae; } \\
13 \text { pupae }\end{array}$ & 7 fresh-hatched callows & $\begin{array}{l}0 \\
0 \\
0 \\
0 \\
0 \\
0 \\
0\end{array}$ \\
\hline $\begin{array}{l}\text { ther } \\
\text { colonies } \\
\text { grouped }\end{array}$ & $\begin{array}{r}9 / 9 / 62 \\
10 / 22 / 62 \\
1 / 5 / 63\end{array}$ & $\begin{array}{l}2 \text { pupae } \\
8 \text { pupae } \\
0 \text { (2 male }\end{array}$ & $\begin{array}{l}1 \text { fresh-hatched callow } \\
\text { e-producing nests) }\end{array}$ & $\begin{array}{r}0 \\
0 \\
10 \text { pupae }\end{array}$ \\
\hline
\end{tabular}

Thus over a period of two years and four months, beginning four and one-half months after capture, a single colony of $R$. tasmaniensis produced I 7 I worker pupae or fresh-hatched adults, another 8 , and a third contributed two worker pupae and a single adult. Two further (and small) groups contributed Io male pupae. Once again the evidence for worker production is very clear.

*I am especially appreciative of the help given in obtaining the Hobart material by Mr. John Hickman of the University of Tasmania. 


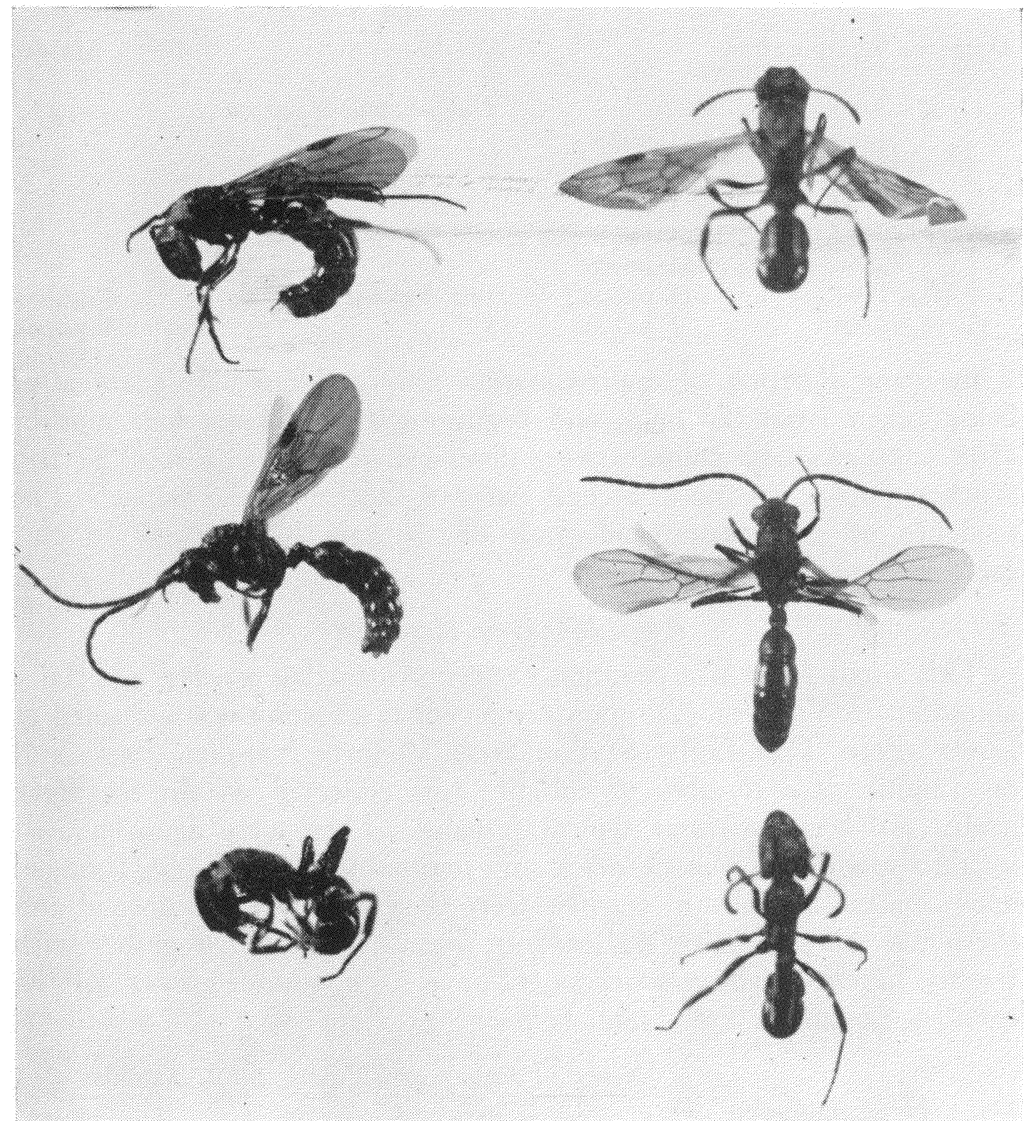

Fig. 1. Alate Female, Male, and Worker of Rhytidoponera metallica.

\section{Rhytidoponera inornata}

This species, also allied to $R$. metallica but normally, according to Brown (I958) having a range allopatric to it, is a typical resident of extreme southwestern Australia. Two colonies without typical queens were collected at Manjimup, West Australia, between December 25 and 27, 1959, and housed in the usual glass modified Lubbock nests. As in the preceding instances, cocoons were removed at intervals after a suitable beginning period, opened and scored for sex and caste. The totals from the two colonies on each examination have been pooled. The results follow: 


\section{Dates of Examination}

$5 / 5 / 60$

$5 / 14 / 60$

$5 / 18 / 60$

$6 / 15 / 60$

$6 / 20 / 60$

$7 / 23 / 60$

$3 / 1 / 64$

$6 / 22 / 64$
Assay of Pupal and Young Adult Samples

Workers $\longrightarrow$ Males

1 fresh-hatched callow

1 pupa

1 pupa

1 pupa

1 pupa

51 pupae

33 pupae; 13 fresh-hatched callows $\quad 5$ pupae

7 pupae

4 pupae

Thus over a period of approximately four and one-half years after being taken from the field, and beginning five and one-half months after capture, these colonies were observed to produce a total of Iog worker pupae or fresh-hatched callows, and 9 male pupae. The evidence of consistent production of workers by workers in this species seems clear.

\section{Rhytidoponera victoriae}

This small form is a common eastern Australian species, especially abundant in Victoria. On January 2, 1962, a colony was collected at Lower Fern Tree Gully Station, near Victoria National Park, and on January 3 a number of colonies was collected within the Park itself. All were without typical females. They were again housed in glass modified Lubbock nests, and maintained until May, 1962, in open arenas. Samples of cocoons were then removed and opened and the pupae scored for sex and caste in the usual manner, together with freshly hatched callow workers. The results, summed over all the colonies examined, are shown below:

Dates of Examination

$5 / 19 / 62$
$8 / 3 / 62$
$8 / 24 / 62$
$9 / 16 / 62$
$10 / 14 / 62$
$10 / 22 / 62$
$7 / 2 / 64$
$7 / 15 / 63$
$9 / 21 / 64$

Assay of Pupal and Young Adult Samples

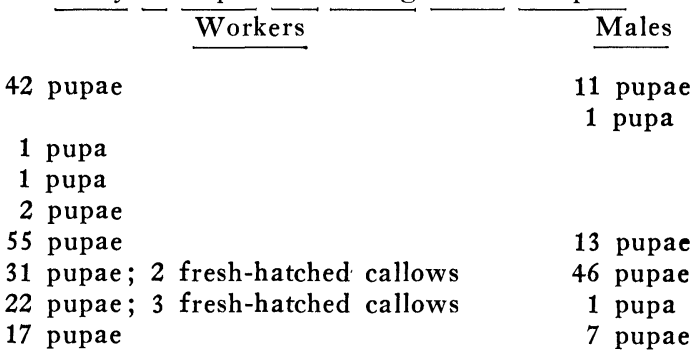

Thus over a period of twenty-eight months a total of $\mathrm{I} 76$ workers is known to have been produced and a total of 79 males - good evidence once again that in this species worker production by workers is the rule. 


\section{Rhytidoponera violacea}

This is an example of one of the larger species of the genus, in which alate females have never been observed. It is a typical inhabitant of rather dry country in southwest Australia, and closely resembles in appearance and habit the better known $R$. convexa of the eastern half of the continent. A single colony of $R$. violacea taken in Kings Park, Perth, W. A., on December 30, 1959, was maintained in an earthfilled modified glass Lubbock nest through January, i965. Throughout this five-year period abundant broods of young workers were produced, together with a few males. On October 26, I964, 3 cocoons were extracted from this colony and opened and their contained pupae scored for caste and sex, and a second sample of 8 was similarly examined on October 27. All eleven pupae were of workers. Thus worker production from workers was continuing four years and ten months after the colony was taken.

In three of the five species of Rhytidoponera investigated ( $R$. metallica, $R$. inornata, and $R$. victoriae) perfect queens are represented in collections, though with great rarity in all except $R$. metallica. A fourth, $R$. tasmaniensis, is so closely similar to $R$. metallica that it is hard to imagine that similar alate females do not occur with it too, and that their absence from collections does not simply reflect the fact that this species has not been particularly extensively taken. Yet in all these species (together with the fifth, $R$. violacea, where alate females have never been found and, from all the circumstantial evidence, probably do not occur) worker production by individuals themselves morphologically indistinguishable from normal workers is clearly the rule. Males of the species, of course, must also be derived from workers. The question thus is posed whether worker production by workers results from thelytokous parthenogeny, or whether fertilization of workers, in the pattern of Diacamma, is the rule.

THE MODE OF PRODUCTION OF WORKERS BY WORKERS IN THE NORMALLY "QUEENLESS" SPECIES OF RHYTIDOPONERA

In a series of careful and extensive histological studies of workers of Rhytidoponera metallica, $R$. inornata, and $R$. violacea collected in the field, R. M. Whelden (1957, 1960, and unpublished data) has conclusively demonstrated that a normal fertilization mechanism is involved in the production of workers by "workers." Examination of the spermathecae of a total of 836 workers of these three species yielded the results shown below: 


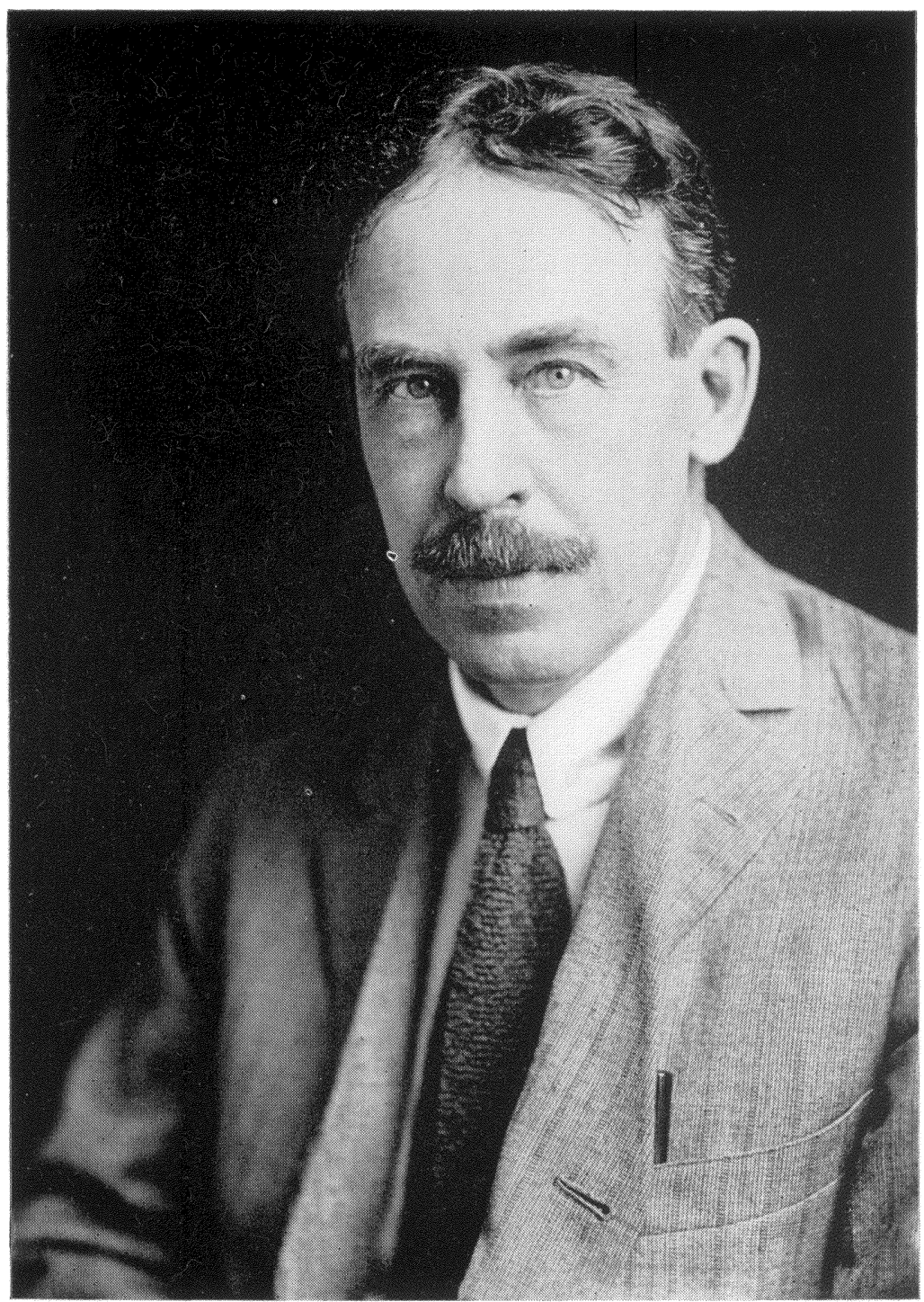

William Morton Wheeler

MARCH 19, 1865 - APRIL 19, 1937

PROFESSOR OF ENTOMOLOGY, HARVARD UNIVERSITY I 908-I937 


\begin{tabular}{|c|c|c|c|}
\hline Species & $\begin{array}{l}\text { Number } \\
\text { in } \\
\text { Sample }\end{array}$ & $\begin{array}{c}\text { Number } \\
\text { Individuals } \\
\text { with } \\
\text { Sperm }\end{array}$ & $\begin{array}{c}\text { Per Cent } \\
\text { Individuals } \\
\text { with } \\
\text { Sperm }\end{array}$ \\
\hline R. $\overline{\text { metallica }}$ & 386 & $2 \mathrm{I}$ & 5.4 \\
\hline$R$. inornata & I 76 & 4 & 2.3 \\
\hline R. violacea & 274 & 22 & 8.0 \\
\hline
\end{tabular}

It thus seems clear that thelytokous parthenogenesis at least is not usual in these species of Rhytidoponera, and that a normal mechanism of fertilization is involved in the production of worker progeny. Other questions concerned with an estimate of the average relatedness among workers in a single Rhytidoponera colony, earlier posed, are thus raised. It becomes important, for example, to ascertain whether single or multiple insemination of workers is the rule, whether individual workers may be inseminated more than once during their lifetimes, and to what degree outcrossing among different colonies obtains. These issues, of course, can only be determined by careful and complete observations of the mating flight. Our observations are still very incomplete. Since, however, they have provided answers to one or two such questions, even at this preliminary stage, they are presented here.

\section{CHARACTER OF THE MATING FLIGHT IN RHYTIDOPONERA METALLICA}

Some field evidence of the fertilization of workers by males in Rhytidoponera metallica has been obtained by W. L. Brown, Jr. (unpublished observations). He noticed males in low flight which alighted and entered the main gallery of an established nest of the species. There seems to be no observational record, however, of actual fertilization of workers. We have been so fortunate as to witness this.

A colony of $R$. metallica, cited earlier in another connection, was collected at Sutherland, N. S. W., Australia, on June I, I952. As already described, it was housed in a modified earth-containing glass Lubbock nest, and was then maintained for three months at $15-17^{\circ} \mathrm{C}$, within the normal winter temperature range of its environment. During this period workers were allowed to forage from the nest in a closed arena, and were supplied dilute honey continuously and provided frequently with a considerable variety of living insect prey. On September 3, I952, the nocturnal temperature was raised to $20^{\circ} \mathrm{C}$, and diurnal temperatures were allowed to reach a maximum of $25^{\circ} \mathrm{C}$. Two days after this temperature rise, a number of males which had matured in the nest during the cool period left it and wandered over 
the crater. Simultaneously, several workers were observed resting quietly outside the nest and in its near vicinity, with head and thorax rather closely appressed to the substrate on which they rested, but with the gaster held high and arched. The impression was strong that an attractant was being disseminated. Males which had emerged from the nest but had not yet flown paid no special attention to these individuals. Freshly emerged males, indeed, neither flew nor ran to any great extent, but went through extensive cleaning motions near the nest, and were frequently deported back into it by foraging workers which met them by chance. Nothing further occurred at this time.

On the morning of September 6, with an ambient temperature of $22^{\circ} \mathrm{C}$, ten workers were observed resting quietly near the nest crater with head and thorax appressed and gaster raised. They remained immobile in this position for a measured minimum of I minute 5 seconds to a maximum of $\mathrm{I} 2$ minutes IO seconds. Six were finally deported back to the nest by foraging workers encountering them apparently by chance. At the same time a few males emerged, and, after preliminary cleaning and running about, flew briefly. Nothing further occurred.

On September 7, with ambient temperature of $24^{\circ} \mathrm{C}$, males emerged in some numbers and flew actively. Foraging workers encountering such males became greatly excited and commonly attacked them at once. After approximately one half hour of more or less continuous flight, a few males alighted near the nest crater and, running rapidly, sought out nearby workers. No obvious selection was made of workers resting immobile with raised gasters, although a few of these were still present. As soon as a male encountered a worker, it grasped the worker in the cervical region with the mandibles and, thus firmly attached, at once inserted the stipes. The mandibular grip was then relaxed at once, and the male, with wings folded, was maintained in a nearly vertical position by the stipes alone. The first and third pairs of legs of the male were characteristically folded, while the second pair projected upward so that they were pressed against the costal margins of the wings. Both members of the pair usually rested quietly in this position for a few seconds. Thereafter the worker characteristically executed grooming movements and began to move about, and almost at once seized the male by the thorax with the mandibles and forcibly disengaged it. On a few occasions the worker began to move almost as soon as copulation began, dragging the male and dislodging it after progressing for an inch or two.

The first copulation was observed at 8:50 A.M. and lasted for 40 seconds. Between that time and ro:50 A.M., ten matings were 


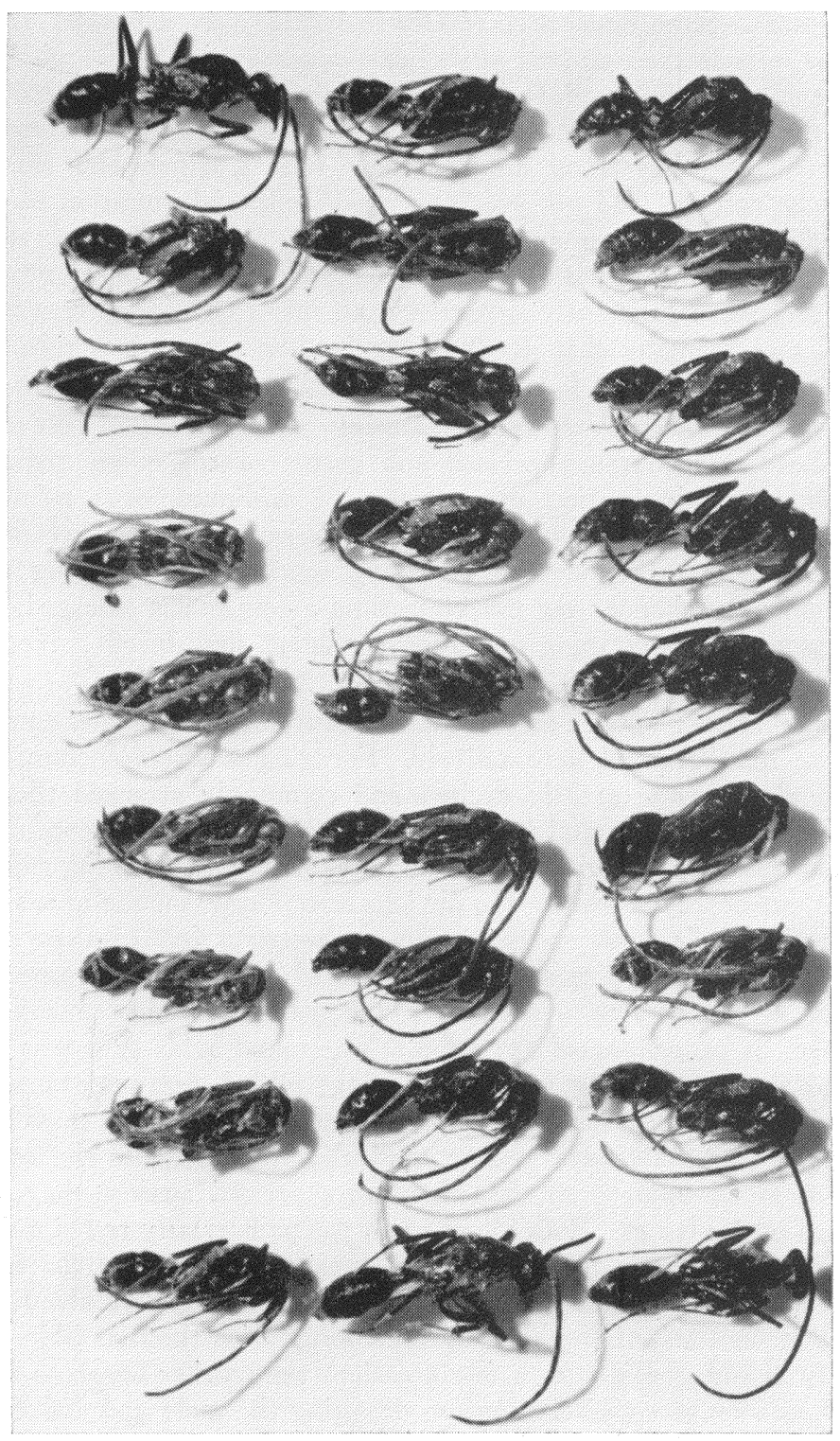

HASKINS - RHYTIDOPONERA 
closely watched and timed. Pairs remained in copula from a minimum of 30 seconds to a maximum of 52 seconds. It was noted with special interest that in one case the same pair copulated twice; in another an individual male paired successively with two workers. In two instances workers reentered the parent nest while still in copula.

All males observed sustained active flight for periods up to one half hour before seeking to copulate. The final stages of search, however, were accomplished in every case on the ground. The whole process was suggestive of the mating pattern observed in certain Ponerine species (such as Amblyopone australis and A. (Stigmatomma) pallipes - Haskins and Haskins, I95 I Haskins, I928) where the alate female flies only occasionally and with reluctance but emerges from the parent colony to mate on the ground or on low vegetation. The vigorous pattern of dispersive flight and the general hyperactivity of the males during the flights seemed conspicuously adapted to securing outcrossing between colonies of the species. Such outcrossing, indeed, may be biologically essential, as will later be indicated.

No detectable morphological features distinguished workers which mated from those which did not. The group which was fertilized included both among the smallest and among the largest individuals in the population, as well as many in an intermediate range. This observation confirms the conclusion of Whelden (1957; 1960) derived from his histological investigations, that workers showing sperm content in the spermatheca included individuals of a wide range of size.

A second nuptial flight of identical pattern was observed in this nest on January 27, 1957. Shortly after 9:00 A.M. of that day male exodus and flight began in typical fashion, reaching a peak by I0:30 A.M. On October I7, 1952, July I 7, 1953, and November 22, I953 workers of this colony were again observed resting outside the nest with gasters elevated, but on these occasions there was no corresponding flight of males. Precisely this same behavior of workers has been observed with colonies of Rhytidoponera tasmaniensis, $R$. inornata, and $R$. violacea, all housed in the usual type of modified, earthcontaining Lubbock nests. The intervals for which the position was maintained were similar to those in $R$. metallica. Males have been seen to fly actively from a nest of $R$. violacea, closely simulating the pattern of flight in metallica. Actual mating has not been observed in these species, but it seems a probable inference that the pattern is similar.

Explanation of Plate 6

Late male Pupae of Rhytidoponera purpurea, from Brood Matured in Artificial Nest in Fragment Without Brood Queen. 
Thus it is clear that both female and male behavior patterns in $R$. metallica are well adapted to secure outcrossing among colonies as a usual condition of the mating flight. Furthermore, multiple insemination of one worker, and insemination of more than one worker by a single male, can occur. The related question of whether a single worker can be inseminated several separate times during its life span has not yet been answered, nor has the question of whether newhatched workers, after insemination, may return permanently to the parent colony to add to its reproductive potential and prolong its life beyond the limit of two generations so usual in Formicid communities. It may be suggestive in this connection, however, that not all of the worker spermathecae that contained sperm were found by Whelden to be filled. Indeed, of 22 individuals of $R$. violacea found to contain sperm, among a sample of 274 examined, in only two were the spermathecae completely occupied by a dense sperm ball of cells. In three individuals the sperm mass was very small and loose, comprising only an estimated 50-IOO cells. In the remaining cases, the spermathecae were partially filled, though fully inflated.

All the evidence seems very suggestive that a rather high degree of heterozygosity must indeed be regularly maintained in colonies of $R$. metallica, involving the germplasm of populations greatly exceeding the single colony in numbers. It became of considerable interest, therefore, to enquire what might be the limits of viability in a single colony where strict inbreeding was enforced over several worker generations.

\section{TOLERANCE OF RHYTIDPONERA METALLICA TO \\ EXTENSIVE INBREEDING}

In this context, certain further observations made on the colony of $R$. metallica already cited may be of interest. As already described, this colony was maintained throughout the ten years of its existence as a set of "closed" populations, from which no individuals could escape and which none could enter from the outside. By the time that its two longer-lived sections died out, at ages respectively of 9 years 6 months and Io years 2 months, many new generations of workers had been matured, to be fertilized in turn by successive generations of males of the same colony. It is not possible to assess quantitatively the degree of homozygosity finally attained in these two populations. It must have increased very considerably, however, over the years. It is therefore of special interest to note that in the last months of the lives of both sections ova, although continuing to be produced in numbers, characteristically failed to hatch larvae. A cytological examination of these eggs by Whelden (unpublished) showed a high degree of 
abnormality in embryonic development. Examination of II9 eggs from the two colony fragments showed the greater number to be uninucleate. A few contained 2-4 small nuclei, tending to be clumped abnormally at one pole of the egg. In a very few cases embryonic development was sufficiently advanced to show some segmentation and to indicate the polarity of the embryo, but this was all. By contrast, a control sample of eggs taken at the same time from a colony housed and treated in the same manner but much more recently collected showed clear evidence of development in over 80 per cent of ova examined, ranging from early stages showing masses of well-defined cell nuclei to late and well-formed embryos.

Such evidence suggests that the maintenance of a rather high degree of female heterozygosity is no less a biological imperative for Rhytidoponera than for Formicid species possessing alate queens and exhibiting highly organized mating and dispersion flights involving both sexes. Indeed, the evidence for multiple insemination of workers suggests that it may be considerably more dependent than some species. It seems probable that a system of sex-locus lethal or semilethal alleles exists similar to that described by Mackensen (1951, 1955) and Rothenbuhler ( 1957) for Apis, and originally in Habrobracon by Whiting (1943). It would seem that such a requirement of heterozygosity, in the context of the kind of colony organization displayed by the "queenless" species of Rhytidoponera, must complicate the maintenance of close genetic relationships among workers within a colony.

THE FORMATION OF NEW COLONIES IN R. METALLICA

Central to the problem of whether successive generations of fertile workers remain in older colonies is the question of how new colonies are formed. At present it is uncertain what may be the normal life course of young workers subsequent to fertilization in a parent colony. Some observations have accumulated, however, which may bear on the mode of formation of new colonies in $R$. metallica.

Workers taken at random from established colonies in the artificial nest and isolated in new nests regularly attempted to initiate fresh communities. They secreted themselves in partly closed cells, from which they emerged occasionally to forage in the fashion typical of normal colony-founding Ponerine queens, laid eggs and tended them carefully, reared larvae, and in a number of cases matured adult progeny. Unfortunately, it has not so far proved possible to distinguish and select fertilized workers for these experiments, and all progeny reared by such isolated workers have been males. Had worker progeny been reared, however, a new colony might easily have arisen.

Thus it seems at least plausible that isolated workers of $R$. metal- 
lica, if fertilized, may be capable of founding new colonies. It seems somewhat more likely, however, that under natural conditions new colonies are normally formed by the detachment from the parent nest of worker groups which include one or more fertilized individuals. Even though initially very small, such parties may expand rapidly in numbers and reach the status of full-fledged colonies in a remarkably short time. Thus on December 21, 1963, two isolated groups of workers were taken at Sutherland, N. S. W. One consisted of 7 workers, about 6 cocoons, and a few young larvae; the second, also of 7 workers, with 2 cocoons and about 6 young larvae. These two groups were colonized in the usual fashion in modified earth-containing nests, and housed throughout their history in adjacent arenas on the same laboratory table. On January I7, 1965, the first group included the following:

74 living adult workers.

127 dead workers found on the kitchen middens.

* 4 dead males found on the kitchen middens.

55 cocoons, which were opened and examined, and found to contain:

26 worker pupae.

9 semipupae, believed to be of workers from the size and shape of the cocoon.

* $\quad 11$ male pupae.

7 semipupae, believed to be of males from the size and shape of the cocoon.

2 fresh-spun cocoons with larva present.

54 larvae of various sizes.

Several groups of eggs, totaling about 100 .

Thus at least 227 workers and 15 males had matured to the pupal stage and beyond. In sharp contrast, the second group at the same date was found to contain 5 adult workers (almost certainly of the original 7), 2 males, and 3 cocoons, 2 of which contained male pupae and the third a semipupa. Thus this group as collected apparently had not included a fertilized worker.

It is particularly interesting, in view of the normally nonseasonal production of males in $R$. metallica, that at least 15 males were matured within the first year of life of this colony. This situation may be contrasted with the case of a colony of Ectatomma ruidum** kept under observation, from its establishment by the original female, over a ten-year period in the artificial nest. Here no males whatever appeared until near the close of the fourth year of community life.

*Note presence of males at this early stage in colony development.

**An abundant New World Ectatomiine species with a well-defined alate female caste, forming communities which are commonly if not always monogynic. 
THE PRODUCTION AND FUNCTION OF ALATE QUEENS IN

\section{R. METALLICA}

As earlier mentioned, fully developed alate queens of at least four normally "queenless" species of Rhytidoponera, with bulky thoraces and typically large compound eyes have been collected — though rarely - in the field. Under what conditions are they produced? And what is their function?

On September 25, 1955, and again on October 23, 1955, a single typical female was found in a colony of $R$. metallica described earlier, which had been collected near Sutherland, N. S. W., in June, I952. When discovered, each individual was already dealate, was actively foraging and feeding outside the nest with workers, and generally was behaving precisely like a worker. When isolated in an earth-containing modified Lubbock nest each female at first made an imperfect beginning of an isolated cell, behaving in the general fashion of an isolated worker. Neither female formed a true cell, however, and neither showed any sign of oviposition, so typical of isolated metallica workers. One female remained passive for a full month, and when at the end of that period it was lost, no trace of an established nest could be detected. The second female behaved in precisely the same manner and was ultimately killed and fixed for histological and cytological examination.

On October 7, 1954, during one of the flights of males from the same colony, two alate females, matured within the nest shortly before, emerged with the males and workers and ran actively about outside the nest. They showed no disposition to mate, however, and were ultimately captured and preserved.

In January, 1957, the same colony produced about twenty perfect females. On January 19 one of these emerged from the nest and wandered about for a short time. It shortly reentered without having flown. Eight days later, between 9:00 A.M. and ro:30 A.M., while a flight of males was in progress and several workers were resting motionless with elevated gasters, a dealate female made a number of trips together with workers to and from the nest carrying excavated soil and quite unaffected by the flight in progress. At I I :OO A.M. an alate female emerged from the nest and wandered briefly before returning, but gave no evidence either of dispersal flight or of any attempt to mate.

On February 2 a further dealate queen emerged and wandered. On March 15 yet another young alate female emerged simultaneously with three males, wandered, vibrated the wings briefly, then, without mating or making further attempts at flight, dealated in the open and 
returned to the parent nest. During the same day four additional females behaved in a similar pattern.

Another colony of $R$. metallica, taken at Ashton Park, Sydney, N. S. W., on January 8,1964 , had by May 20 produced two perfect females. Both emerged from the parent nest while still alate and perished shortly thereafter, having shown no disposition to found new colonies.

This sketchy evidence of the production and behavior of perfect females in $R$. metallica surely needs to be augmented. It does suggest, however, that in this species the true female is indeed an evolutionary remnant, in which innate behavior patterns governing emergence from the nest, the undertaking of at least rudimentary flight, and dealation are retained. Behavior leading to colony foundation, however, seems feeble, or actually absent, and replaced by a marked tendency to rejoin the parent colony and assume a worker-like function within it. It is of course impossible yet to be certain that abnormal environmental conditions may not have been responsible for this aberrant behavior, and the isolated dealate female of $R$. inornata found by Wheeler may be suggestive. But the virtual absence of true brood queens in normal wild colonies surely suggests both that colony foundation by isolated fertile females, if it occurs at all, must be seldom successful in competition with the mode observed, and that the longevity of such queens, even in the parent nest, can hardly be considerable. They indeed appear to be of relict-like character.

What brings about the occasional production of perfect females? In the two colonies where such production has been observed, it occurred at the height of the brood-rearing season, and at a period when the colony was most active in foraging and was most abundantly supplied with food. In each colony, the total brood of females was produced over a rather short interval, suggesting that trophic influences may have been important in effecting the crossing of a "difficult" developmental barrier. Quantitative studies of the phenomenon, analogous to those of Brian in Myrmica, are needed.

\section{DISCUSSION AND SUMMARY}

The work reported has shown that workers are regularly produced from worker eggs in five species of Rhytidoponera in which alate females are rare or unknown. On the other hand, worker-laid ova give rise only to males (though prolifically) in $R$. purpurea, a species in which normal queens are the rule. Males are also regularly and copiously produced from worker eggs in artificially maintained colonies of $R$. metallica which appear to lack worker-producing individuals. These observations suggest that sex determination in 
Rhytidoponera is of the normal Formicid type, and thelytokous parthenogenesis, if it occurs at all, does not make a significant contribution to the production of females. Such a conclusion has been strengthened by the observation of nuptial flights and actual mating of males with workers in $R$. metallica. It has been physically proven in the finding by R. M. Whelden of sperm in the spermathecas of workers in $R$. metallica, $R$. inornata, and $R$. violacea.

It is clear from the evidence of collections that, at least in $R$. metallica, $R$. inornata, $R$. victoriae, $R$. aspera, $R$. croesus, and $R$. strigosa, in addition to the members of the $R$. impressa group, normal alate queens are produced under natural conditions. Numerous such queens of $R$. metallica have been matured in the artificial nest. These undertook some flight and dealated but neither mated nor made any attempt to found new colonies, although conditions were made as nearly optimal as possible. They proved uniformly very short-lived. This evidence, taken with the fact that perfect females have never been reported in a considerable number of species of Rhytidoponera including some of the largest and most conspicuous, and the fact that no queenworker intermediate has been reported for any species, suggest that the queen-form has been entirely dropped out in the "queenless" species, and that members of the $R$. metallica group (and possibly some other forms as well) may be in an intermediate stage of evolution, the queen persisting as a rare morphological form but being virtually without biological significance. This impression is strengthened by evidence both that individual workers, in contrast to queens, do show strong instincts of colony formation, and evidence that groups of as few as seven workers collected in the field can quickly expand to full colony size.

While such observations answer some questions about the general biology and social structure of the "queenless" species of Rhytidopo$n e r a$, they raise a great many more. Whelden's finding of sperm in worker spermathecae in $R$. metallica, $R$. inornata, and $R$. violacea brought out two additional points of interest. First, sperm-containing individuals were relatively abundant in typical colonies of all three species collected in the field, ranging from 2.3 per cent of total workers in $R$. inornata to 8.0 per cent in $R$. violacea. Second, in only a few cases were worker spermathecae replete with sperm. Usually they were but partly filled, and in several instances only a very few sperms were present. This raises the question of whether an individual worker is fertilized more than once in its lifetime, or whether it is normally exclusively male-producing in the latter part of life.

It is clear, at any rate, that numerous worker-producing workers 
coexist in normal colonies of at least three species of Rhytidoponera. Further, in $R$. metallica at least, multiple insemination of workers, and insemination by individual males of more than one worker are not uncommon. It is also evident that workers can and do make rich contributions of male progeny, which may begin to appear (in small numbers) very early in the life of an isolated, expanding, worker group. All these circumstances make it seem improbable, at first glance, that an average degree of relatedness among members approaching sibship can be maintained in a typical Rhytidoponera colony. The situation might be quite different, however, if a single fertile individual normally dominated oviposition in a colony, rival fertile individuals being suppressed by hormonal or behavioral means. Whether any such situation obtains remains to be determined.

If the relatedness of workers within a single colony is indeed relatively low (at least not consistently maintained at the sibship level), it may well be that among the members of a continuous population of the species it is more than usually close. For if new communities normally arise from small parties containing at least one fertilized worker which leave parent colonies, it seems probable that the average distance traveled before settling down would be considerably less than that covered by actively flying queens before founding new communities. One might indeed expect the Rhytidoponera population to be considerably more "viscous," in Hamilton's term, than those of such an ant genus as Lasius, and might perhaps reasonably expect a lesser degree of "colony integrity" than in a monogynous species with actively flying alates of both sexes. Some measure of the degree of colonial integrity developed among those Rhytidoponera species normally without alate females might be gained by a careful study of "colony recognition" between communities - of the degree of worker-to-worker hostility among individual colonies of the same population, as compared to that between colonies from populations considerably separated geographically. Work of this character is planned.

Brian, M. V.

\section{REFERENCES}

1959. The ontogeny of insects. Acta symposii de evolutione insectorum, Praha, 167-171.

1961. Organ transplants between ant castes. Symposia Genetica et. biol. it., Atti IV Congresso U.I.E.I.S., Pavia, 9-14, Settembre.

Brown, W. L., JR.

1954. Systematic and other notes on some of the smaller species of the ant genus Rhytidoponera Mayr. Breviora (Harvard Mus. Comp. Zool.) $33: 1-11$. 
1958. Contributions toward a reclassification of the Formicidae. II. Tribe Ectatommini (Hymenoptera). Bull. Mus. Comp. Zool. Harvard, 118 : 175-362.

1960. Female dimorphism and colony organization in social Hymenoptera. Division of labor in ants. Symposium including papers presented at the 1960 meeting of the Entomological Society of America, Atlantic City, New Jersey, November 28-December 1.

Chauvin, R., G. Courtois, and J. Lecompt

1961. Sur la transmission d'isotopes radio-actifs entre deux foumilières d-espècés différentes (Formica rufa et Formica polyctena). Insectes Sociaux 8: 99-107.

Cомsтоск, A. B.

1903. Quoted in Wheeler, W. M. (1903).

Crawley, W. C.

1912. Parthenogenesis in worker ants, with special reference to two colonies of Lasius niger Linn. Trans. Ent. Soc. London, 657-663.

Haldane, J. B. S.

1955. Population genetics. New Biology, 18: 34-51 (edited by M. L. Johnson).

Hamilton, W. D.

1964. The genetical evolution of social behavior. I. Jour. Theoretical Biology, 7: 1-16.

1964. The genetical evolution of social behavior. II. Jour. Theoretical Biology, 7 : 17-52.

Haskins, C. P.

1928. Notes on the behavior and habits of Stigmatomma pallipes Haldemann. Jour. N.Y. Ent. Soc., 36 : 179-184.

Haskins, C. P., and E. V. Enzmann

1945. On the occurrence of impaternate females in the Formicidae. Jour. N.Y. Ent. Soc., 53: 263-277.

Haskins, C. P., and E. F. Haskins,

1951. Note on the method of colony foundation of the Ponerine ant Amblyopone australis Erichson. Amer. Midl. Nat. 45: 432-445.

KENNEDY, J. S.

1961. Continuous polymorphism in locusts - Insect PolymorphismKING, R. L. Symposium no. 1, Royal Entomological Society, London.

1949. Mixed colonies in ants. Proc. Iowa Acad. Sci. 56: 367-370.

1955. Winged workers in the ant, Formica obscuriventris clivia Creighton. Proc. Iowa Acad. Sci. 62: 509-513.

KInG, R. L., AND R. M. SAlleE

1951. More mixed colonies in ants. Proc. Iowa Acad. Sci. 58: 487-489. Ledoux, A.

1949. Recherche sur la biologie de la fourmi filieuse Oecophylla longinoda Latr. Ann. sci. nat. Zool. et biol. animale, 12: 313-461.

1954. Recherches sur le cycle chromosomiques de la fourmi filieuse Oecophylla longinoda Latr. Insectes Sociaux 1: 149-175. 
MACKensen, O.

1951. Viability and sex determination in the honeybee (Apis mellifera L). Genetics 36: 500-509.

1955. Further studies on a lethal series in the honeybee. Jour. Hered. 46: $72-74$.

Oтто, D.

1960. Zur Erscheinung der Arbeiterinnenfertilität und Parthenogenese bei Kahlrückigen Roten Waldameisen (Formica polyctena Forst.). Deut. entomol. Z., 7: 1-9.

REICHENBACH, H.

1902. Ueber parthenogenese bei ameisen und andere beobachtung an ameisenkolonien in küntslichen nestern. Biol. Centralbl. 22: 461465.

RothenBuHLER, W. C.

1957. Diploid male tissue as new evidence on sex determination in honey bees. Jour. Hered. 48: 160-168.

SOULIÉ, J.

1960. Des considerations écologiques peuvent-elles apporter une contribution a la connaissance du cycle biologiques des colonies de Cremastogaster. Insectes Sociaux 7: 283-295.

Sturtevant, A. H.

1938. Essays on evolution. II. On the effects of selection on social insects. Quart. Rev. Biol. 13: 74-76.

WhEELER, W. M.

1933. Colony Founding Among Ants. Harvard University Press, Cambridge, Mass.

Wheeler, W. M., and J. W. Chapman

1922. The mating of Diacamma. Psyche, 29: 203-211.

WHELDEN, R. M.

1957. Anatomy of Rhytidoponera convexa. Ann. Ent. Soc. Am. 50: 271-282.

1960. Anatomy of Rhytidoponera metallica. Ann. Ent. Soc. Am. 53: 793-808.

Whiting, P. W.

1943. Multiple alleles in complementary sex determination of Habrobracon. Genetics 28: 365-382.

WigGLESWORTH, V. B.

1954. The physiology of insect metamorphosis. Cambridge University Press.

Williams, G. C., and D. C. Williams

1957. Natural selection of individually harmful social adaptations among sibs with special reference to social insects. Evolution 11: $32-39$.

WiLson, E. O.

1958. Studies on the ant fauna of Melanesia. III. Rhytidoponera in western Melanesia and the Moluccas. IV. The tribe Ponerini. Bull. Mus. Comp. Zool. Harvard 119: 303-371.

1959. Adaptive shift and dispersal in a tropical ant fauna. Evolution 13 : $122-144$. 

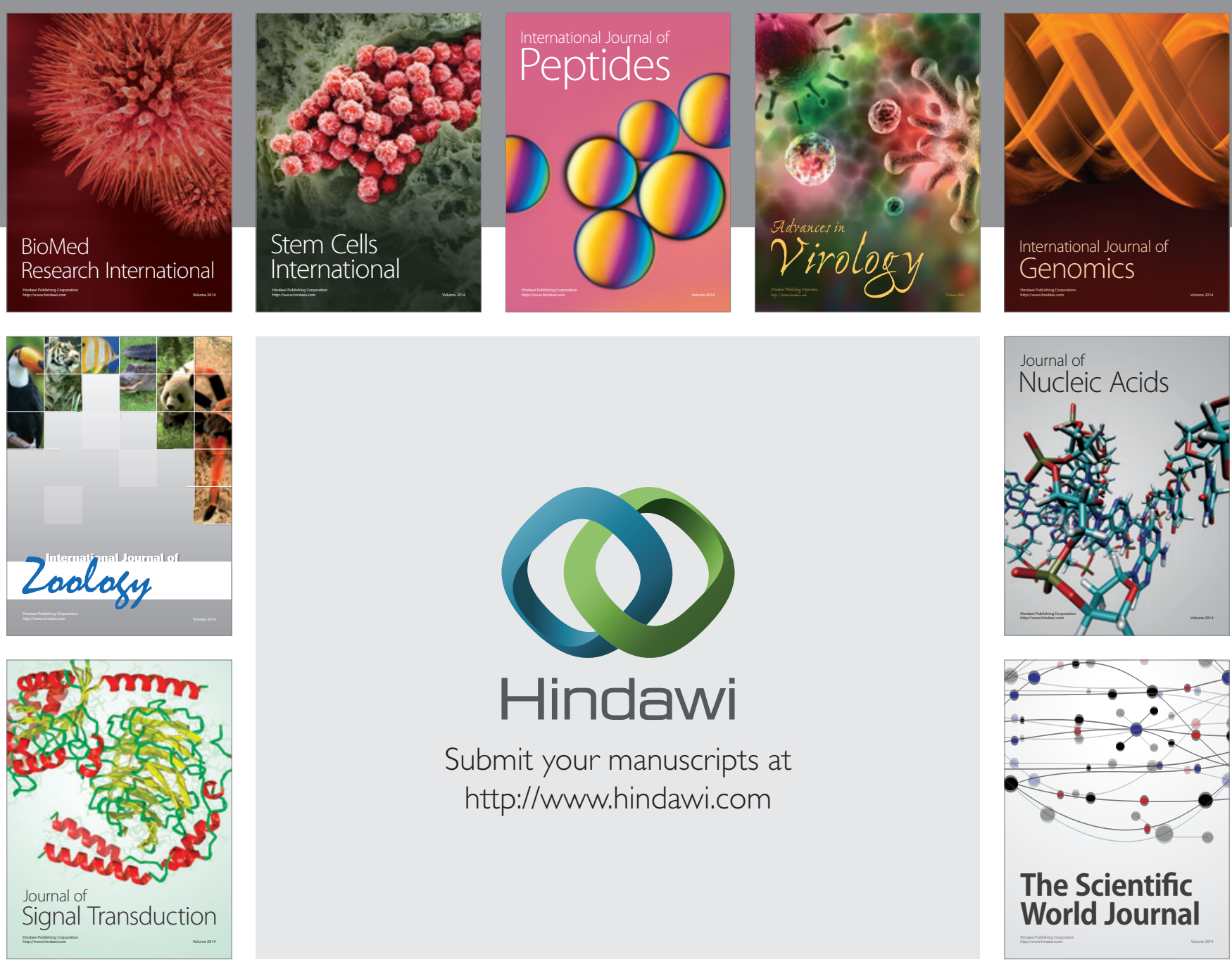

Submit your manuscripts at

http://www.hindawi.com
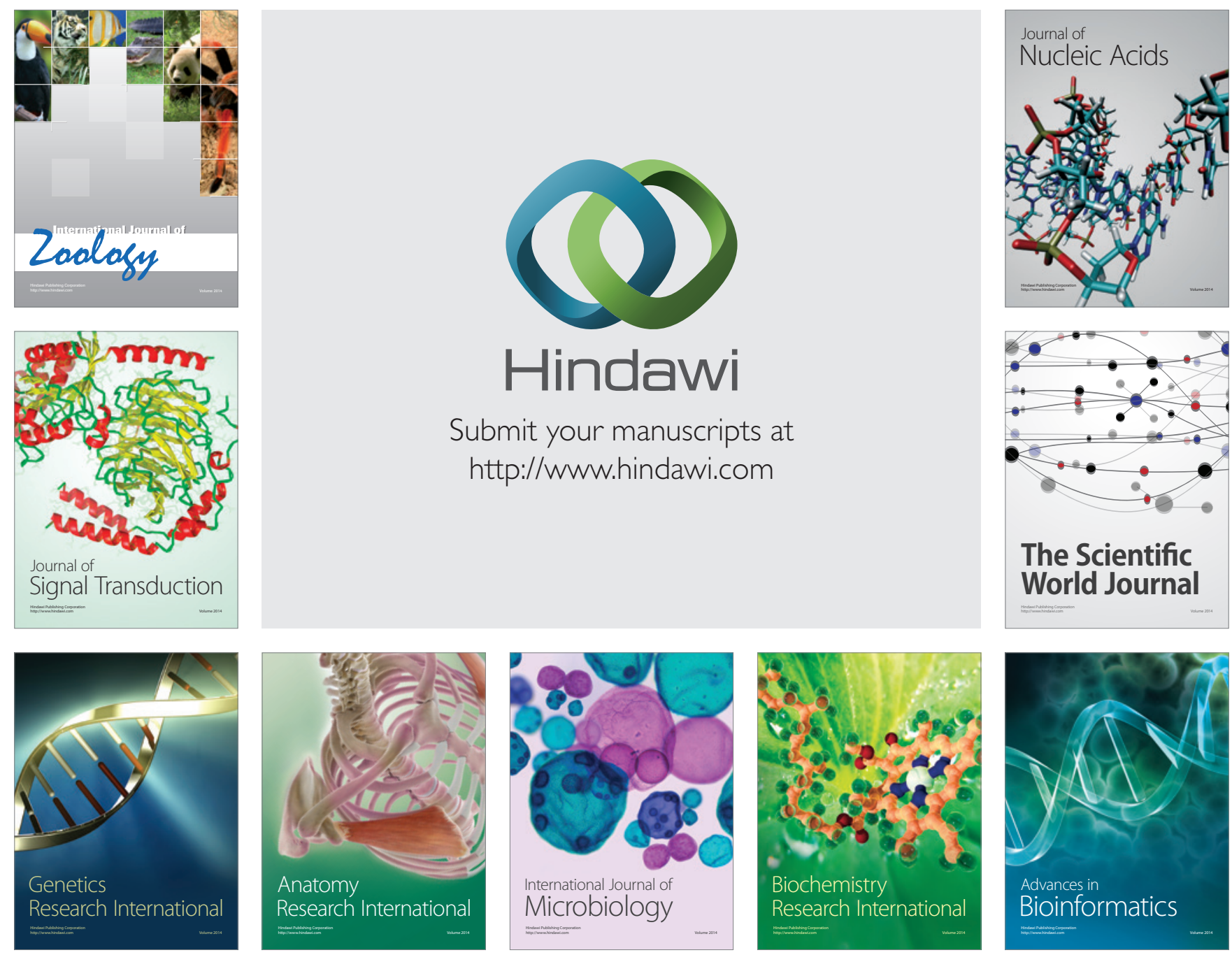

The Scientific World Journal
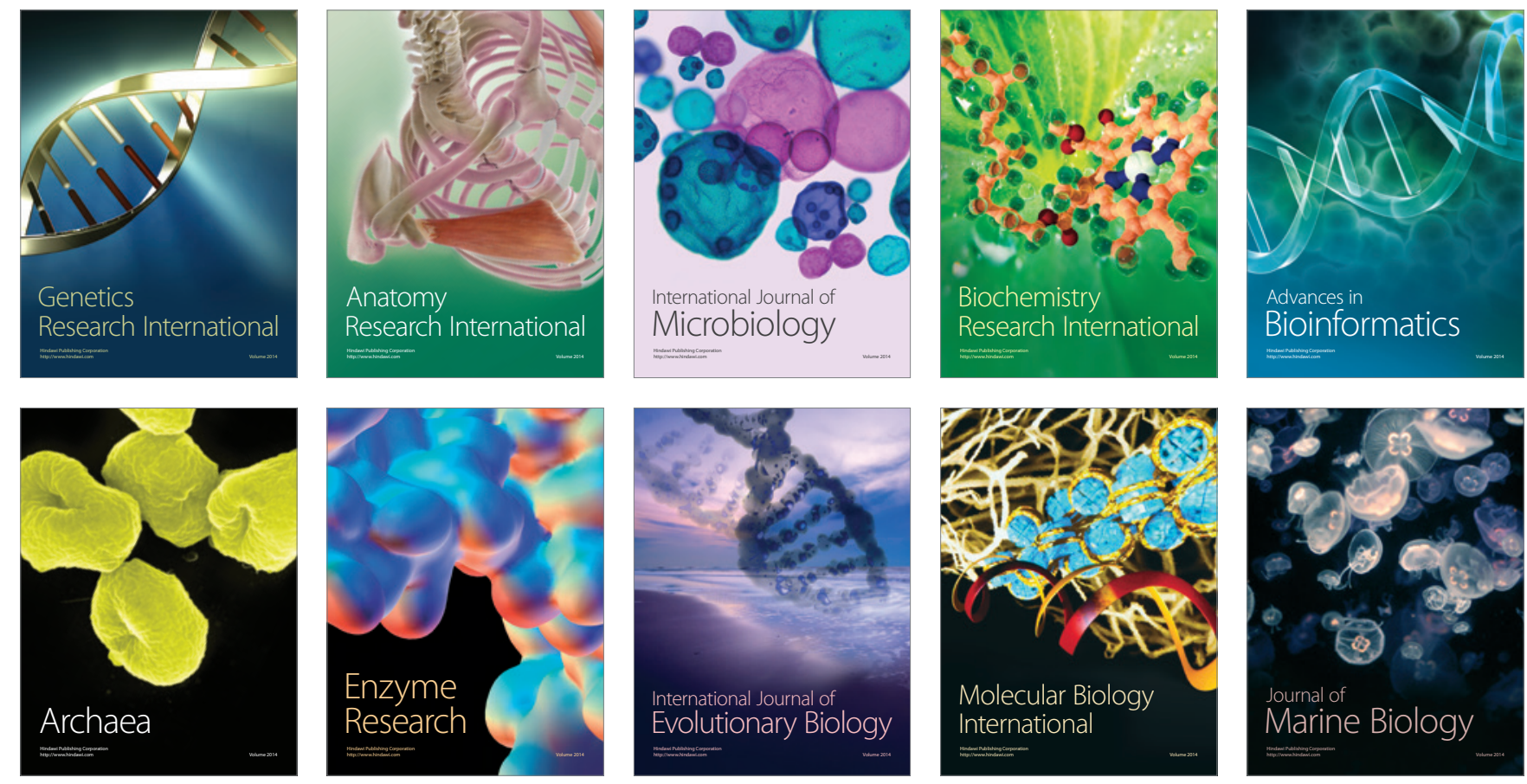